\title{
Improper Technical Guidance Faced by Officials of Insurance Firm
}

\author{
T. Subha Latha, M. Sankar, N. Mathan Kumar
}

\begin{abstract}
LIC occupy a major role by rendering devoted services to the public. The Public approach LIC employees for gathering information about new arrivals of LIC, details about policy surrendering, premium payment and settlement of claims. In addition to that they are engaged in records maintenance work. So, they work under acute pressure. This create greater stress situation among them. Hence, at attempt is made to study the level of stress among LIC employees.
\end{abstract}

Keywords: LIC, Maintenance work.

\section{INTRODUCTION}

High levels of stress also affected the employees ' morale and motivation. Long-term stress exposure without effective coping mechanisms could result in a host of physical and mental problems. Stress, for example, can lead to gastrointestinal problems caused by stress, irritable bowel syndrome, acidity, acid reflux, insomnia, anxiety, heart disease, etc[1]-[8]. In addition, pressure may drive the victim into high-risk habits such as cigarettes, drinking, and abuse of drugs. Stress-related disease has led to an increase in absenteeism and attrition that affects organizations ' profitability. The Public approach LIC employees for gathering information about new arrivals of LIC, details about policy surrendering, premium payment and settlement of claims. In addition to that they are engaged in records maintenance work. So, they work under acute pressure. This create greater stress situation among them. Hence, at attempt is made to study the level of stress among LIC employees.

\section{OBJECTIVES}

- To portray an overview of stress and job stress.

- To analyse the socio economic profile of LIC employees.

- To examine the reasons for the stress

- To measure the level of stress among LIC employees

\section{A. Scope of the study}

This research is confined to the study of socio-economic variables such as age, gender, employment, marital status, family size, number of earned members, family form, LIC employee experience and monthly incomes. In a competitive world, stress arises due to many reasons[9]-[15]. These

Revised Manuscript Received on December 11, 2019

T. Subha Latha, Department of Science and Humanities, Bharath Institute of Higher Education and Research, Chennai , India. Email: subhalatha.thavasikannan@gmail.com

M. Sankar, Department of Science and Humanities, Bharath Institute of Higher Education and Research, Chennai , India. Email: sankar06.phd@gmail.com

N. Mathan Kumar, Department of Science and Humanities, Bharath Institute of Higher Education and Research, Chennai, India. Email: ma.aswinkumar18@gmail.com reasons are analysed to find out the major reason for the stress. The level of stress among LIC employees is also measured.

\section{B. Limitation of the study}

1. The LIC employees are selected from Chennai.

2. In Chennai, only 250 employees are selected due to time and cost constraints.

3. The results of the study may vary from time to time due to psychological feelings of the respondents.

\section{Area of the Study}

The area of the study is Chennai. It is a capital of our State. In and around Chenani, there are so many tourist places. The head office of LIC is situated in Chennai. It has 14 floors and it is one of the largest company buildings in Chennai. There are many industries functioning in Chennnai

\section{REVIEW OF LITERATURE}

Mala (2000) pointed out in the article "Stress Among Co-operative Bank Employees" that over workload is a major reason for the stress. The employees in Co-operative society are engaged in repetitive work. They felt that extra working hours is a drawback. It may affect their performance and it is a hurdle for their future advancement.

Kannan and Manohar (2002) stated in their article "A Study On Stress Among College Librarians, Kovilpatti" that library is considered as a temple of knowledge. In that place, the role of librarian is more important. Both students and faculties approach librarian for availability of books, details about renewal and return procedures. It is the duty of the librarian to give details about books to the needy people continuously. This will create monotony in their work. This creates stress among them[16]-[19].

Guru (2005) in his project "A Study on Level of Stress Among LIC Employees in Madurai" suggested that poor monetary benefits affect the economic position of the employees. In order to meet the financial needs, they borrow money from banks and financial institutions. They have the responsibility to pay the interest for their borrowings and repayment of debt. This burden is a reason for the stress. He suggested that the LIC management should revise the monetary benefits from time to time to safeguard their employees from financial crisis[20]-[22]. 


\section{RESEARCH METHODOLOGY}

The current study is based on primary and secondary data. The primary data was gathered from 250 LIC employees through well structured questionnaire. For the recruitment of 250 LIC workers, convenience random sampling technique was adopted[23]-[25].

The primary data collected has been coded and tabulated for analytical purpose. The primary data collected from LIC employees has been analysed by using suitable statistical tools.

\section{RESULTS AND CONCLUSION}

Out of nine socio economic variables age, sex, education, occupation , martial status, family size, type of the family number of earning members in a family, experience and monthly income, only one valuable 'marital status' is not significantly related among LIC agents.

Improper working conditions (991), over burden of work (973) and lack of social status (929) one the major three reasons for the stress. It is worthy to note that most of the respondents $184(73.6 \%)$ have medium level stress.To conclude that measure such as free time for the agents and physical exercise are recommended to the agents of the LIC. So that the stress level will be decreased and to have a increased productivity too.

\section{REFERENCES}

1. Vasanthi, S. \& Rabiyathul Basariya, S. 2019, "Influence of value analysis and cross training in industry", International Journal of Engineering and Advanced Technology, vol. 8, no. 6, pp. 1810-1811.

2. Velvizhi, R., Sri Gowtham, S. \& Jeya Priya, D. 2019, "Examination of early feedbacks for effective product retailing on E-commerce websites", International Journal of Engineering and Advanced Technology, vol. 8, no. 6 Special Issue 2, pp. 703-706.

3. Anuradha, C., Pothumani, S. \& Kavitha, R. 2019, "A novel method towards E-commerce", International Journal of Engineering and Advanced Technology, vol. 8, no. 6 Special Issue 2, pp. 535-538.

4. Thomas, J. \& Rabiyathul Basariya, S. 2019, "A study on the issues of financial ratio analysis", Indian Journal of Public Health Research and Development, vol. 10, no. 3, pp. 1079-1081.

5. Ramachandran, S. \& Rabiyathul Basariya, S. 2019, "Online marketing study on customer satisfaction and relationship", Indian Journal of Public Health Research and Development, vol. 10, no. 3, pp. 1072-1078.

6. Priya, R., Vinothini, G. \& Cor Jesu, C.D. 2019, "The mentor-protégé relationship for professional growth", Journal of Advanced Research in Dynamical and Control Systems, vol. 11, no. 9 Special Issue, pp. 1110-1119.

7. Jannifer Rani, N., Bina Pani, S. \& Nimisha, N.S. 2019, "A study on money back polices available in LIC", Journal of Advanced Research in Dynamical and Control Systems, vol. 11, no. 9 Special Issue, pp. 833-839.

8. Saillaja, V., Jhansi Rani, K. \& Catherine, R. 2019, "Global marketing management planning and organization", Journal of Advanced Research in Dynamical and Control Systems, vol. 11, no. 9 Special Issue, pp. 489-493.

9. Saillaja, V., Jhansi Rani, K. \& Catherine, R. 2019, "The new phase of marketing information system", Journal of Advanced Research in Dynamical and Control Systems, vol. 11, no. 9 Special Issue, pp. 482-488.

10. Thoufiqulla \& Raju, D.V. 2019, "Perception of indian investor towards investment in mutual funds with special reference to mip funds", Journa of Advanced Research in Dynamical and Control Systems, vol. 11, no. 5, pp. 177-183.

11. Jasmine, K.R.M. \& Basariya, S.R. 2018, "A study on the customers benefits on mutual funds", International Journal of Civil Engineering and Technology, vol. 9, no. 4, pp. 45-48.

12. Vasanthi, S. \& Basariya, S.R. 2019, "Pros and cons of on the job training versus off the job training", International Journal of Scientific and Technology Research, vol. 8, no. 10, pp. 671-674.
13. Pavithra, J. \& Ganesan, M. 2016, "A study on awareness and impact of micro-financial schemes", International Journal of Applied Business and Economic Research, vol. 14, no. 8, pp. 5449-5460.

14. Pavithra, J., Dilli Babu, P. \& Ambuli, T.V. 2014, "A study on budgetary control at Maruti Service Masters, Chennai", International Journal of Applied Business and Economic Research, vol. 12, no. 2, pp. 151-161.

15. Gunaraja, T.M. \& Venkatrama Raju, D. 2018, "Determining factors of organisational climate with reference to leadership styles", International Journal of Mechanical Engineering and Technology, vol. 9, no. 9, pp. 1327-1332.

16. Gunaraja, T.M. \& Venkatrama Raju, D. 2018, "The role of job satisfaction and training of employees in determining organisational climate of a selected industry", International Journal of Civil Engineering and Technology, vol. 9, no. 8, pp. 1266-1269.

17. Aarathy, T.S. \& Raju, D.V. 2018, "Performance appraisal and its effects on employees with respect to it sector in Chennai city", International Journal of Civil Engineering and Technology, vol. 9, no. 6, pp. 1535-1538.

18. Aarathy, T.S. \& Raju, D.V. 2018, "Employee perception towards performance appraisal system in IT sector", International Journal of Mechanical Engineering and Technology, vol. 9, no. 5, pp. 131-135.

19. Porselvi, W., Jublee, D. \& Sivanesan, G. 2018, "A study on factors influencing adoption of technology and innovation in banking industry, tamilnadu, India", International Journal of Mechanical Engineering and Technology, vol. 9, no. 5, pp. 789-800.

20. Akessa, G.M. and Dhufera, A.G., 2015. Factors That Influences Students Academic Performance: A Case of Rift Valley University, Jimma, Ethiopia. Journal of Education and Practice, 6(22), pp.55-63.

21. Miller, G. and Shih, C.C., 1999. A faculty assessment of the academic rigor of on-and off-campus courses in agriculture. Journal of Agricultural Education, 40, pp.57-65.

22. Tsinidou, M., Gerogiannis, V. and Fitsilis, P., 2010. Evaluation of the factors that determine quality in higher education: an empirical study. Quality Assurance in education, 18(3), pp.227-244.

23. Farooq, M.S., Chaudhry, A.H., Shafiq, M. and Berhanu, G., 2011. Factors affecting students' quality of academic performance: a case of secondary school level. Journal of quality and technology management, 7(2), pp.1-14.

24. Fitsilis, P., Gerogiannis, V. and Anthopoulos, L., 2014. Ontologies for software project management: a review. Journal of Software Engineering and Applications, 7(13), p.1096.

25. Adams, J.D. and Jaffe, A.B., 1996. Bounding the effects of R\&D: an investigation using matched establishment-firm data(No. w5544). National bureau of economic research.

\section{AUTHORS PROFILE}

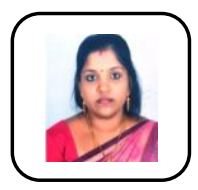

T. Subha Latha Assistant Professor, Department of Science and Humanities, Bharath Institute of Higher Education and Research, Chennai, India.

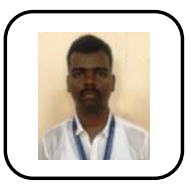

M. Sankar Assistant Professor, Department of Science and Humanities, Bharath Institute of Higher Education and Research, Chennai, India.

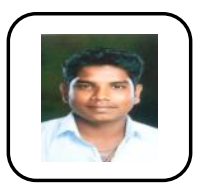

N. Mathan Kumar Assistant Professor, Department of Science and Humanities, Bharath Institute of Higher Education and Research, Chennai, India. 